\title{
Beast in the Barrier Zone: Transformations of Irish Politics, History and Myth in Neil Jordan's Sunrise With Sea Monster
}

\author{
Av Karin Möller, universitetslektor i engelska
}

\author{
Länk till presentation av Karin Möller
}

\begin{abstract}
A cultural world will thrive as long as it retains confidence in its stories. When those stories prove unreliable, when they cease to correspond with lived experience and no longer seem to work ... then that world is in trouble. For this reason imperialists have long recognized that you will reduce a conquered people to subjection more quickly if you demean the dignity of their language and demoralize belief in the validity of their myths. (Clarke, p. xi)
\end{abstract}

The historical Keltoi, whose origin in central and eastern Europe is still partly obscure, expanded in various directions all over Europe. In Britain they met with opposition from both Romans and, later, northern European tribes. As a result of this they were pushed on to the fringes of the British Isles (Clarke, pp. xii-xiii). The interests of the Celts and the Germanic peoples then clashed forcefully again in Ireland during the Viking invasions, when the northerners were encroaching on both Irish territory and Irish culture, without managing to monopolize either. In discussing the cultural tradition developing from the time of Edmund Burke and Matthew Arnold and their way of looking upon these historic events, Seamus Deane reminds us of how the Celts used to be identified in the public mind with the Catholics, and the "Teutons" with the Protestants (p. 26). These sweeping analogies tie in largely with the long story of political and religious divisions, which led to the bisection of Irish society that we are familiar with in our own time. The Celtic heritage, however, has proved viable, and the Irish apparently retain great confidence in their stories. The novel Sunrise With Sea Monster (1996) by the Irish writer and film director Neil Jordan is proof of this; Jordan reveals a keen interest in Irish politics, history, and religion, blended with a large dose of myth. It is interesting to note his attempt to handle the historic dyad of continuity and betrayal, which Deane likewise traces back to the writings of Burke and Arnold. "Continuity," Deane explains, was considered equivalent with Celticism and the Catholic faith, whereas "betrayal" came to be associated with the Protestants in the North (pp. 26-7). However, as I shall argue, Jordan's narrative seeks to come to terms with this overdetermined dyad, rather than conducting a polemic strictly from within the tradition where it originated.

"Betrayal", the dyad's most negatively charged term, symptomatically connotes disruption and, concomitantly, violence. David Lloyd notes with regret that violence and resistance are often attributed to the Irish stereotypically as "aberrations" (p. 128). Also in this respect Jordan's work moves to leave colonial prejudice behind, albeit in a manner which has aroused both questions and hostility. Even if much of his work in different genres (novel, short story, film) is indeed about war and political strife, he has been taken to task for being too pacifist, too intent on assimilation of warring factions. His film The Crying Game, for example, came in for a good deal of rather harsh criticism for that reason, after a while, when the overwhelming initial praise of it had subsided. This film, set in London and Northern Ireland, became well-known for the many role figures in it representing different kinds of people in minority positions: homosexuals, cross-dressers, blacks, women, and Irish people. The film critic Joe Cleary is among those who have remained sceptical about the effectiveness of Jordan's way of handling problems relating to the Irish situation. He 
focuses our attention on how all the minority subject positions which Jordan was praised for bringing into the film were in fact "orchestrated so that each effectively neutralizes the other" (p. 262), and he also notes with disappointment that Jordan tends to shun politics in general. This brands the film as "conservative" in Cleary's eyes (p. 265). Another film critic, Kristin Handler, speaks of the film's "failure to convince us that love is the answer" (p. 41). The Crying Game, in short, was praised for confronting important social problems but criticized for not proposing more explicitly political solutions to them. I mention this here because I believe one could raise similar questions concerning Jordan's Sea Monster novel, set in the Irish Republic. Is Jordan's pacifist theme to be looked upon as a diluted form of utopian liberalism, or universalism? Labels like "liberal humanist" and "universalist" are vague and often do not pledge themselves to anything very much.

There is also, unavoidably, the question of myth and Irish postcolonialism, which Clarke touches on in the passage cited at the beginning of this essay. His dual assertion about the significance of myth and the demoralizing effect of stories which "no longer seem to work" prompts questions in a wider sense about the function of myth in Jordan's narrative. The postcolonial and the political are intertwined in the trenchant criticsm of The Crying Game as well as in discussions of continuity and betrayal. If it is signally important that myth be given scope enough to "work" also in contemporary art, in what way can this be achieved? By shifting our attention from the film to the less famous Sea Monster novel, which does attempt to integrate Celtic myth in its narrative and thematic design, we get a broader picture of what Jordan may be trying to accomplish in his work. Luke Gibbons hints in passing to myth in introducing the first published issue of the journal Interventions. As part of an already existing paradigm of myth, "the chimera of 'Celticism'" (p. 27) could be instrumental in shaping conceptions of Irish postcolonialism. The question of Ireland's putative postcolonial status is too complex to fit into the frame of this essay, but Gibbons's turn of phrase, appears faintly evocative of the contradistinctive and other-worldly. It also suggests that Celticism has been rather troublesome. Maybe the rich and colourful Celtic heritage has loomed so large in the minds of the Irish that it is difficult to steer a straight course between clichés and what is genuinely nourishing about the story of national origins which it proffers? The Greek word "chimera" (denoting phantasm, something envisioned and irreal) may also lead one to think of the Irish fabulist tradition. Jordan's fictional sea monster is surely at home in this rich tradition. As a ubiquitous mythic avatar it was evidently inspired by the (non-Celtic) painter J. M. W. Turner, whose painting "Sunrise with Sea Monsters" depicts a strange fish-like creature heralded by the promise of a new dawn as it rises from the sea. Jordan, an artist with certain postmodern leanings, is often unabashedly eclectic. As has no doubt been noted by attentive readers already, the American travel writer Paul Theroux is the first to have "discovered" Turner's magnificent painting. In his book of adventurous travel sketches from 1985, Sunrise with Seamonsters, the title story tells us of a man rowing his boat along the eastern sea coast of America in difficult weather. Also in the Theroux story, which is written in a mainly realist vein, we find certain overtones of the uncanny in the rowing man's summary of his experience: "It had been a disorienting day. At times I had been afraid. It was a taste of something strange in a place I had known all my life. It was a shock and a satisfaction" (p. 348). As Jordan's protagonist Donal Gore was to do nine years later, Theroux ends his difficult day with a meal in the reassuring ambience of the family kitchen. His experience, he says, had been "private", not easy to communicate to others p. (351). Jordan, too, seems intent on fashioning a private vision by synthesizing impulses of different origin. In attempting this, his creative eclecticism and natural bent for mediating between the aesthetic demands of different art forms may be factors that propel him towards a particular conception of transformative myth.

Laurence Coupe, who has written about myth fairly recently, sees fiction as "a means of extending mythology" (p. 4). He stresses the fact that literary works are mythopoeic in that they can give rise to new, mythically derived narratives which are crucial to the ways in which people even today feel urged to read and reread the world they live in. Coupe then differentiates between two ways of handling myth within a narrative framework. Following an allegoristic, "orthodox" view, the story which contains the mythic elements is not 
allowed to deviate too much from the originary conception of these elements. Coupe sees this as myth being "domesticated" by allegory (pp. 105-7). The postmodern conception of myth, by comparison, makes it out to be relativist, non-realist and flexible. This way of looking on myth bestows on artists the freedom to attempt ever new, individual appropriations of myth, regardless of the old matrices. That Jordan's projects tend towards postmodern flexibility of the latter kind was hinted early on by Richard Kearney, who observed about Jordan's very first Irish feature film (which was called Angel), that it "/.../ does not approach the mythical in terms of ancient legend or folklore, but in terms of contemporary lived experience" (p. 298). The two ways of reading myth which Laurence Coupe describes are so different as to appear incommensurable. Yet as we shall see, the themes and the symbolism of Jordan's novel are presented in such a way that it is possible to find traces of both allegorical fixity and transformable myth in it. This, in my view, is one of the most baffling aspects of the novel.

After these preliminaries, let me now turn to the text, in which Jordan foregrounds the emotionally and politically charged "Irish" binaries of past-present, rebellion-peace and, especially, betrayal-continuity. In the novel's opening scene the pre-dawn light falls on the unholy triptych of Franco, the Virgin Mary, and Mussolini, displayed as blown-up posters on the wall of a prison far from Ireland. Donal Gore, a young Irish volunteer in the Spanish Civil War, is awaiting execution there at the hands of the fascists. "Ireland" (the name emblematic as well as geographical) seems endangered from the start, crucified with fascist "robbers" on either side of her. Historically, Ireland, England and Spain have been embroiled in political fighting. "Spain" is, furthermore, the place from which Ireland derives part of its mythic origin. The arrival in Ireland at the beginning of chronicled history of its first invaders, the north-bound Milesians, with a reputed ancestry in the mythical Land of the Dead (Rolleston pp. 96, 138), prefigures the triangular rivalry that was to develop in later historical periods. From the very beginning, then, Spain was seen as an outside party, which was to become a haunting presence in the Elizabethan period. Both in early colonial times and much later, in the Second World War, Spain was England's archenemy and the potential ally with whom Ireland was always tempted to side. A keen sense of history as well as a penchant for sardonic wit support the novel's staging of the allegorical robbers and the Irish Virgin, whose purity is threatened by the courtship of unsightly rival suitors. It implies, I believe, a wish on Jordan's part to maintain, within a nationalist Irish consciousness, an ironic awareness of the role of Catholicism. This may be so even in light of the fact that religion is indeed one of the most influential factors which prompted the Irish to resist British colonialism. The triangular relationship between Ireland, Spain and England then takes on a marked oedipal slant in the novel when we discover that it is paralleled within young Donal Gore's family. Donal and his father used to live in an atmosphere of neutral but brooding silence after the premature death of Donal's mother, who is later replaced in the household by an attractive young piano teacher to whom both men feel drawn. When the father then actually marries the piano teacher, Donal's twisted loyalties make him go all the way to Spain to fight on the Republican side, in a defiant gesture aimed at his father.

As for the father, he has his own complex history of political affiliations. His roots are within the Protestant Ascendancy class but at one point in his youth he turned from it to affiliate himself with the IRA and the struggle for political independence. After the Irish War of Independence and as a result of differences between him and de Valera, he became disillusioned with IRA violence and crossed over to the side of the politicians who advocated the Treaty. Eventually he was offered (and accepted) a political office in the Free State. He had also by then converted to Catholicism, which was his first wife's religion. In the course of only a few years he was thus involved in what one might call serial betrayal, crossing boundary lines which were both political and religious. "Betrayal, then, began with him" (p. 35), as his son Donal rightly perceives. Donal himself ponders the significance of betrayal when he receives an offer in the Spanish prison where he ended up shortly after arriving on the scene of war. Instead of being executed straight away he is given the chance to buy his own freedom by helping Nazi Germany against England, as an Irish go-between. He desists officially but when he gets back home he nevertheless 
engages in underhand dealings with the Germans, as well as with certain IRA members who try to get at their English enemies under the cover of Irish neutrality, a state of affairs with an alleged basis in historical fact (see the prefatory "Note on historical background"). The decision taken by Ireland and other countries to remain neutral in the war resulted in a certain amount of moral unease afterwards. In the case of Ireland, the refusal to join in the large western war in a moment of crisis seemed to many people uncomfortably like sly parochialism, reducing the Irish problems by comparison to "a squabble in a bog", in the phrase of a British reviewer (Kerrigan p. 21). All the same, Jordan gets on with his storytelling, which at first affords us no glimpses of what goes on in Donal Gore's mind during his negotiations with the Germans and the three rather quixotic IRA men who act as their local representatives. Much later we learn that Donal actually chose to walk in his father's footsteps by accepting betrayal as a personal and political stratagem. He engages in a bit of classical double-dealing and hands over the Nazis and their Irish sympathizers to the authorities. More than anything, it seems like a nonchalant touch of slapdash, an ironic appropriation of the generic conventions of thrillers, or spy story plots, which tend to rely on last-minute relief of suspense. Donald P. Haase describes similar strategies deployed in the film The Company of Wolves, which is an adaptation of both an Angela Carter novel and the fairy story of Little Red Riding Hood. Here Jordan consciously strives to appropriate the generic features of language spoken in fairy-tales and to this end he relies on proverbial phrases in order to "deconstruct proverbial wisdom" (p. 97). Arguably, it is Jordan's very adroitness at translating his aesthetic visions from one medium into another which inclines him favourably towards metamorphosis as the most pregnant trope in his art.

It is difficult, at first, to know how Donal himself looks upon his ideological leg-shifting. On the surface of things, this Irish hero relies unashamedly on expediency in order to get by, and in doing so he unwillingly emulates his silent, protean father, who once compromised his ideological convictions. "Deceit, I realised, had become my element", Donal thinks to himself (pp. 142-3). He makes this reflection standing on Sandymount Strand, and immediately afterwards he sees how "a row of cormorants raised their wings to the air, like phoenixes" (p. 143). The sight of the sea birds taking to the air inspires Donal to extricate himself from the static conditions of the dilemma in which he finds himself. Either he must accept the idea of compromising with his republican ideals, just as his father once did in order to stave off gruesome violence, or he will stick to the side of IRA (against Britain), even if this means condoning their morally tainted allies, the Nazis. The choice seems to be a wholly unattractive one of being a renegade or a fascist hardliner. Donal also has to mobilize the purely visceral survival instinct affecting people who fight to stay afloat when tough political challenges come crushing in on them. Does betrayal signify anything that goes beyond the notion of just drifting with the changing political tides? In stepping across political boundaries as both of the two male protagonists of Jordan's novel opt to do, they seem to celebrate this deep Irish historical ambivalence in some tentative and risky way. It is tentative and risky because certainly not everyone would subscribe to a re-definition of the word "betrayal" as an ethically acceptable strategy for action. For many, betrayal cannot ever mean anything but a shameful breach of loyalty. It cannot have anything to do with positive implications of rethinking and change, or with attempts to supersede rigid binarism and an uncompromising partisan spirit. Yet if betrayal, as in the previously mentioned constellation betrayal/continuity, always retains some of its basic connotation of disloyalty and shame, the word in its present context nevertheless seems to call for semantic modification of some kind to enable readers to conceive of change in more positive terms and thus prepare the way for a redirection of the ideological message of the text. How could this be envisaged? A forage into the cluster of related thematic concepts yields the ambivalent notion of compromise. To be compromised in the eyes of other people implies negative action, to have done something whereby one has incurred their low esteem. Making a compromise, however, is a phrase with a more positive ring to it. It implies sacrificing part of one's stake in something for the sake of reaching an effective agreement. The text's playing on the ambivalence inherent in the line of action taken by both father and son converges on the idea of risk-taking, of daring to relinquish a standpoint which implies a serious mismatch of old loyalties and new 
convictions. The ground for the envisioned final reconciliation of father and son is prepared through a surreptitious thematic shift within the narrative.

The novel's key tropes of metamorphosis and transformation are pervasive in that they also pertain subtly to what is tangible and observable in Ireland, namely climatic unpredictability and the sea. The Irish Sea is both an extra-terrestrial barrier zone between nations and a neutral meeting-ground for father and son. It was their habit to set "nightlines" in the evening to catch fish, which they collected early in the morning. Not very much was said during this procedure but it was a peaceful moment of co-operation between father and son, a homely domestic ritual which both of them appreciated. When Donal returns home from Spain he finds his father in a wheel-chair, mute and helpless after a stroke. Now they cannot have any conversations but they keep up their old pre-war habit of setting the night-lines by the water all the same. The night-lines are an evocation of the old Celtic weirs, which were used for catching fish and other treasures yielded by the sea. They were half closed off by stones or wooden branches and dried out in between the tides, when they could be searched for the wondrous treasures they sometimes yielded.(1) The recurring descriptive passages in the novel of the ever present sea and of everything connected with it are lyrical, underscoring the impact of the sea on the minds of the people who live near it. In this sense the Sea Monster novel can be seen as a homage to the Irish, their people and their land.

The tone of the narrative is not always reverential, however, nor is its mood placid. Donal and his stepmother plan a trip to Lisdoonvarna Spa, ostensibly to allow the crippled father to benefit from the healing sulphurous waters but in reality, as Donal alone knows, to enable himself to hand over information to the Germans and their Irish collaborators. Since the IRA was rigorously suppressed by the Irish governments during the second world war (FitzGerald p. 35), any illicit business going on needed to be shielded carefully from the eyes of the authorities. The spa visit is thus only a cover which provides Jordan with an excellent opportunity to make one of his characteristically oblique comments on Celticism. Spas exist and thrive to this day, and the relief of the sick and weary which they generously offer conflates hope with superstition in a way that puts the sanguine to the test. "You don't believe in that" (p. 140) is the incredulous comment which Donal's stepmother quite correctly makes when Donal proposes the Lisdoonvarna visit. Still, Donal manages to convince his stepmother that he sees the magic healing power of the ancient well as the last straw of hope for the crippled father. He then proceeds with the preparations for the spa visit in a curiously shifty mood. He feels annoyed when his contact man mispronounces Irish placenames, on the one hand, but appears himself to be condescendent about the ancient Celtic rites. Any remnant of genuine belief in myth which may still exist in the minds of the faithful Irish (the rather more devotional stepmother, for example) will have to be sacrificed on this occasion for Donal's own purposes. In the presence of his Irish contact man he shrugs off his discomfort at the thought of using his father's illness and visit to the sacred well as a pretext: "We'll dip him [the father] in the sulphur springs and pretend to pray for miracles" (p. 141). So much for the holy springs of Celtic folklore (on sacred wells, see further Rolleston pp. 66-7, and Matthews p. 56). And yet the covert implication of Donal's specious remark is that any healing attempt undertaken in that kind of insincere spirit is destined beforehand to be a failure. It means that the text plays it both ways: it mocks Celticism as obsolete superstition while managing at the same time to preserve a measure of genuine respect for it. What actually happens in Lisdoonvarna later on turns out to be both enjoyable and farcical. On the way there Jordan gives us in passing a lyrical description of a lovely country road that winds on interminably along "the low stone walls, the bent blackthorns, the fields of limestone now interspersed with green" (pp. 151-2). The archaic beauty of the scenery is interrupted by a description of an ancient cave with an absurd, witch-like old woman in black at an entrance with stone slabs leading down into the murky interior. The reader is invited to partake of a light-hearted pleasurekilling of myth in the description that follows of a weird ceremony involving a blind boy who dips his hands in the holy water so many times in languid succession that the healing process seems in the end absurd and "hypnotic" (p. 155). It seems appropriate in this context to recall Seamus Deane's reference to "a spurious Celtic Eden", the idealist notion 
which the Irish are said to adhere to because they were brutally robbed by the English of their traditional past (p. 19). It may well be this notion (the myth about myth, as it were) that Jordan wishes in some measure to puncture. Deane makes the further comment that Irish people tend to "think of tradition as continuity betrayed rather than continuity retained" (ibid.). Whether one takes that position depends, however, very much on one's particular view of mythic function. Jordan's mockingly irreverent attitude in Sunrise With Sea Monster is no doubt also as an attempt on his part to ward off Celticism as a stifling master myth which shapes people's views of the Irish cultural heritage in forms which are too homogeneous and predictable. The idea runs very true to traditional form; Marguerite Quintelli-Neary cites numerous examples of how modern Irish writers (Joyce and Flann O'Brien among them) resort to uninhibited parody in reshaping old myths (p. 20). A certain, freewheeling irreverence has become part of the Irish tradition, a way of handling myth which then blends smoothly into the fluid postmodern conception of myth.

Quintelli-Neary discusses several Celtic motifs of Irish story-telling. Discord between father and son is one of these; going away for awhile to face trials in "nightmarish Otherworlds" (p. 12) is another, reminding us of Donal Gore in the death cell of his Spanish prison where he has to spend a certain amount of time before he goes back to Ireland. Quintelli-Neary points to this as a structural convention of Celtic myth, the "education of the hero" (p. 8). In the old stories the young male character's time away from his family makes him aware of his special responsibilities and unique qualifications as a hero.

The ramifications of Celticism in Jordan's novel are both manifold and diverse. Immediately after the visit to Lisdoonvarna, Donal meets up with his German spy colleagues and the Irish renegades at a place called Spanish Point. It is also at this point where the narrative threads of the plot are drawn together in a tight skein and where the archetypal is most clearly foregrounded. Donal has to leave his father temporarily in the wheel-chair on the beach in order to greet his German friend Hans, whose arrival on the scene is expediently staged with the help of a submarine rising from the sea. Jordan's narrative machinery is smoothly employed to hoist the submarine out of the depth, a sea creature turned modern leviathan in a scene intended as a dress rehearsal before the novel's final transformation takes place. The glaring theatricality of the scene makes it into a benign parody of mythopoeia. Both Marguerite Quintelli-Neary and Miranda Green stress metamorphosis and shape-changing as typical motifs in Celtic mythic stories. Green mentions the Salmon of Wisdom as one of the animals which were an integral part of cult and religion in the pagan world of the Celts (p. 196). Donal has finalized his choice by now and is convinced of the wisdom of handing over Hans to the authorities. He also believes that peace is promoted by his act. As in the case of Michael Collins, Jordan's eponymous film hero, it seems to be revulsion from the more extreme hazards of political struggle, terrorism and outright fascism, which finally triggers Donal's decision to "betray" his comrades.

The lingering resonance of tragedy in this story has to do with the father. When Donal retrieves his wits after the hassle on the beach and remembers that he left him alone for a while, he makes the awful discovery that the father is gone. The empty wheel-chair tells a mute story of someone who must have been submerged by the outgoing tide. At this point in the narrative, realism, too, goes for good. For one morning, as Donal keeps up the old habit of searching the night-lines at "the place where both worlds meet" (p. 172), he suddenly sees his father again, walking towards him in a vision. That is, he first lands a harbinger, a quaint-looking fish,

outsize and majestic, a hooked creature from some lower depths, shuddering occasionally in the morning breeze, quite silver-scaled, eyes bulging and distended, tulip-mouthed, on its forehead a curved and perfect horn. As it flapped, its gills shuddered with the last gasps of air. I /.../ heard a thin pale cry come from it, as it died in the unfamiliar light. (pp. 173-4) 
The Christian-allegorical fish turns out to be the food of communion as the father sits down in the kitchen to share the white fish meat with his son. They talk and the uncomfortable silence between them is broken at last. We are transferred to the realm of myth and fairy-tale in this kitchen where we learn from the son in a classical epic turn of phrase that "the day had gone its course while we spoke and it was approaching evening" (p. 182). Green reminds us that the Celts used to prepare salmon with honey (p. 39), something that is transliterated directly into Jordan's text; in the kitchen where the strange fish is frying in the pan "a magical smell of burnt honey flooded the room". Father and son partake of "flesh that was hardly flesh, fish that was hardly fish" (pp. 175-6) before the father quietly vanishes from the narrative once again.

Strange creatures come out of the depths, to be sure. Hyponoia, which is Plato's term for the hidden meaning of myth, denotes meaning and understanding as coming from below. The realistic, Irish locality of the sea, grey and choppy, represents these mythical nether regions where revelation is being prepared. Christian allegory (a paradigmatic, essentialist mode of employing myth) merges with the Celtic, which Jordan has made freer and more idiosyncratic use of. Jordan's understanding of the Celtic heritage makes him reshape it in alternate moods of celebration and parody. Metamorphosis and "betrayal" (the word itself subject to change) underpin the story's narrative and thematic movement. A classic universal theme (reconcilation) is honoured in this story about the monster that metamorphoses into a redemptive fish, but universality is qualified by an emphasis also on the strictly personal: father and son sealed off in a hazy vision beyond the reach of others. Basically, it is the same critique as was voiced in the case of The Crying Game, of Jordan's preference for the non-political and the private. Lori Rogers, in her analysis of Jordan's novel The Dream of a Beast, expresses well that which Jordan has been reproached for: "Only in seclusion /.../ can two people (seemingly just two, no more) find acceptance, that purity of desire that can be defined as learning to desire, not what we are conditioned to, the surface of things, but what is internally real" (p. 54). This is true, an yet the Sea Monster novel's validation of the universal, through one of its most celebrated pagan and Christian symbols, the honeyed, sacrifical fish, is not encoded in the narrative in particularly idyllic terms. The reconciliation is achieved through "betrayal", political crossover manoeuvres, painful deliberation of impossible-seeming decisions, which demand from the individuals that they forgo the ease of a comfortable conscience. The twin ideas drifting slowly to the surface of this story, of compromise (for peace) as betrayal (of partylines and political loyalty), and betrayal (moving towards a new ideological stance) as compromise (tainted with ambivalence), instead etch into the reader's mind an ironic awareness of the impossibility of pure action.

\section{(C) Karin Möller}

\section{Note}

1. The Tale of Taliesin (one of the tales in the Celtic Mabinogion collection) is a good example of a story featuring weirs. Taliesin is a boy child who gets fished out of a weir and tells his astonished listeners a story of marvellous metamorphosis.

\section{Works Cited}

Clarke, Lindsay. Essential Celtic Mythology. London: Thorsons (HarperCollins), 1997.

Cleary, Joe. "'Fork-Tongued on the Border Bit': Partition and the Politics of Form in Contemporary Narratives of the Northern Irish Conflict". The South Atlantic Quarterly, 95:1 (1996), pp. 227-276.

Coupe, Laurence. Myth. London: Routledge, 1997.

Deane, Seamus. Celtic Revivals: Essays in Modern Irish Literature 1880-1980. London:

Faber and Faber, 1985. 
FitzGerald, Garret. "Ceaselessly Split by History". Time Magazine, Aug. 31, (1998), p. 35.

Gibbons, Luke. "Ireland and the Colonization of Theory". Interventions, 1.1 (1998/99), p. 27.

Green, Miranda. Animals in Celtic Life and Myth. London: Routledge, 1992.

Haase, Donald P. "Is Seeing Believing? Proverbs and the Film Adaptation of a Fairy Tale". Proverbium, 7 (1990), pp. 89-104.

Handler, Kristin. "Sexing The Crying Game: Difference, Identity, Ethics". Film Quarterly, 47:3 (1994), pp. 31-42.

Jordan, Neil. Sunrise With Sea Monster. London: Vintage, 1996 (1994).

Kearney, Richard. "Avenging Angel: An Analysis of Neil Jordan's First Irish Feature Film". Studies. An Irish Quarterly Review, 71. 283 (1982), pp. 296-303.

Kerrigan, Michael. "Republican Prisoners", Times Literary Supplement, Jan. 13 (1995), p. 21.

Lloyd, David. Anomalous States: Irish Writing and the Post-Colonial Moment. Durham:

Duke UP, 1993.

Matthews, John. King Arthur and the Grail Quest: Myth and Vision from Celtic Times to the Present. London: Blandford, 1994.

Quintelli-Neary, Marguerite. Folklore and the Fantastic in Twelve Modern Irish Novels. Westport, Connecticut: Greenwood Press, 1997.

Rogers, Lori. "'In Dreams Uncover'd': Neil Jordan, The Dream of a Beast, and the BodySecret". Critique. Studies in Contemporary Fiction, 39.1 (1997), pp. 48-54.

Rolleston, T. W. Myths and Legends of the Celtic Race. Second rev. ed. London: George G. Harrap, 1949 (1911).

Theroux, Paul. Sunrise With Seamonsters. London: Penguin, 1985. 